\title{
A REVIEW OF THE CRITERIA OF THE PREDICTION OF STUDENTS' CREATIVE SKILLS IN THE VISUAL ARTS EDUCATION
}

\author{
Kani ULGER (D)* \\ Sivas Cumhuriyet University, Education Faculty, Fine Arts Education Department \\ 58140 Sivas, Turkey
}

Received 4 January 2020; accepted 24 July 2020

\begin{abstract}
This study aimed to predict the creativity in the painting area of students in visual arts education. This study reviews conducted on the publications. In this review, eight categories were classified related to the creativity by a hierarchical method as follows: definition, components, assessment, measurement, criteria, tests, scoring, and the art. According to the content analysis, the categories were originality, fluency, flexibility, boundary-breaking independent, unconventionality, and perspective which were determined as universal criteria for general content regarding creativity measurement. However, the aesthetic, technical skill, imagination, elaboration, closure, and idea generation were identified as specific criteria for the creativity measurement regarding the painting in the visual arts education. This review study indicated that the creative skills of students in the visual arts education can be predicted by the criteria in which a combination of the universal and specific criteria inclusively.
\end{abstract}

Keywords: creativity, creativity measurement, creativity tests, criteria, visual arts education.

\section{Introduction}

Creativity, as an idea or product, transforms into an existing thing into a new one (Csikszentmihalyi, 2013). In this manner, creativity is a kind of human skill that can be used in a project or a work, which is an important trait in every area from engineering to the art (Hokanson \& McCluske, 2016). Creativity includes multiple conceptual factors as personal, cognitive processes, environment, and product. According to Batey (2012), this approach seems to have accepted in a wide consensus among scholars. Although there are many invented creativity measurements on these factors, there is a need for creativity measurement in specific areas because of the creativity measurement should not be based on just general content. Therefore, measurement of creativity is an important subject (Plucker \& Makel, 2010; Viskontas \& Miller, 2013) and this issue addresses in a wide variety of fields (Fink \& Benedek, 2013). However, creativity in art has been frequently confused with artistic talent (Zaidel, 2013). Whereas, the creativity in the art can be different regarding disciplines of

${ }^{\star}$ Corresponding author. E-mail: kulger@gmail.com

Copyright (c) 2020 The Author(s). Published by Vilnius Tech Press

This is an Open Access article distributed under the terms of the Creative Commons Attribution License (http://creativecommons. org/licenses/by/4.0/), which permits unrestricted use, distribution, and reproduction in any medium, provided the original author and source are credited. 
visual, music, dans etc. For instance, the creativity in visual arts discipline should be needed different assessments (Diket \& Brewer, 2011). Because, creative traits in painting can exhibit different characteristics from the other disciplines (Weinstein et al., 2014).

United Nations Educational, Scientific and Cultural Organization (2006) reported that all individuals possess creative skills potentially, and art supports an individual's creativity. Art encourages children to construct their creative ideas (Jolley, 2019). However, it is difficult to find any favorable criterion on what is known about creativity when we look at children (Csikszentmihalyi, 2013). Possible criteria for the creativity measurement exists in the art activities for children because of the art supports their imagination and creativity (Irish National Teachers' Organization, 2019). The art education is one of the best tool for nurturing creativity (United Nations Educational, Scientific and Cultural Organization, 2006) and, the visual arts education possesses specific role to play in fostering individuals to be creative (Alter, 2010). The painting involves visual things as a visual arts product. Therefore, children easily express themselves by drawing before telling her/himself (Ulger, 2015) and they exhibit in the painting their imagination infinitely. So what do we do in this situation in the name of assessment of their painting? In terms of the visual arts education, Mannathoko and Mamvuto (2018) stated that assessment in the visual arts education was not sufficient. According to them, there are a few reasons for this situation. One of them is that teachers' limited knowledge of appropriate assessment procedures. The other is that the teacher only considered the measurement of children's artistic growth and development. Broome (2016) found that many art teachers' preferences in the assessment were based on the professional development needs of them. Whereas, a necessary assessment ought to build on the students' development needs. As Hallam, Hewitt, and Buxton (2014) stated, the art teachers should assess artwork to help develop children's art appreciation. Mannathoko and Mamvuto (2018) recommended scholars a common approach to this area to the measurement of creativity. However, there are already many creativity tests in general use but, these tests have also limitations. Therefore, alternative tests should be developed (Clapham, 2004) and further research need to be implemented in this area (United Nations Educational, Scientific and Cultural Organization, 2006). At this point, Russ A. Schultz (2002) emphasized that the proper assessment is only useful when it is done appropriately.

From this perspective, it can be forwarded that creative skill prediction is a prominent topic in visual arts education. As Sabol (2004) stated, the creativity measurement in art education would be beneficial for both teachers and students. However, there has not been any attempting to searching some properties of criteria about predict creativity in visual arts education. The main aim of this study is to predict creativity in the painting of students in visual arts education. Accordingly, the research question of this study was determined as follows:

Q1. What do the criteria to predict creativity in the painting of students in visual arts education?

\section{The sample and data collection}

This study conducted a systematic literature review of creativity on publications published over the last decades between 2000 and the first quarter of 2018. In this study, a keyword search was used to review these publications, which was creativity term. Also, snowball 
sampling strategy was implemented to increase the study samples. In this way, the study sample was enlarged to 141 publications as related to the search subject (Boise State University, 2019). The snowball sampling strategy provides searching on the cited source in the publications. This sample was classified into 16 categories by their contents. Subsequently, as a search strategy, a set of inclusion/exclusion criteria was conducted on each category (Table 1).

Thus, eight categories for the study sample were determined by the inclusion/exclusion criteria as direct or indirect terms as related to the search subject respectively as followed: 1 - definition of (creativity), 2 - components, 3 - art with, 4 - assessment, 5 - measurement, 6 - criteria measurement, 7 - (creativity) tests, and 8 - scoring measurement (Table 2).

The inclusion/exclusion criteria provide to determine which trait can be included or excluded from the study sample. The inclusion criteria involve traits for research subject without confusing matters, whereas the exclusion criteria contain insufficient characteristics for the research subject (Garg, 2016). The inclusion and exclusion criteria were described as direct or indirect related factors to search the subject for this study sample correspondingly. Accordingly, eight categories with the inclusion of 75 publications were determined and analyzed in terms of their content for this study (Appendix).

Table 1 . The classified papers as 16 categories (source: created by author)

\begin{tabular}{|c|c|c|c|c|c|}
\hline \multirow{2}{*}{ Categories } & \multirow{2}{*}{$\begin{array}{c}\begin{array}{c}\text { Inclusion } \\
\text { criteria: }\end{array} \\
\begin{array}{c}\text { direct } \\
\text { related to } \\
\text { category }\end{array}\end{array}$} & \multirow{2}{*}{$\begin{array}{c}\begin{array}{c}\text { Exclusion } \\
\text { criteria: }\end{array} \\
\text { indirect } \\
\text { related to } \\
\text { category }\end{array}$} & \multicolumn{3}{|c|}{ Type of production } \\
\hline & & & Article & $\begin{array}{l}\text { Book/ book } \\
\text { chapter }\end{array}$ & $\begin{array}{l}\text { Dissertation/ } \\
\text { report or text }\end{array}$ \\
\hline Assessment & 12 & 6 & 14 & 3 & 1 \\
\hline Measurement & 9 & 6 & 14 & 1 & - \\
\hline Criteria & 12 & 7 & 14 & 5 & - \\
\hline $\begin{array}{l}\text { Gender difference in } \\
\text { creativity }\end{array}$ & 3 & 2 & 4 & 1 & - \\
\hline Scoring & 5 & 1 & 6 & - & - \\
\hline Product (creative) & 1 & - & 1 & - & - \\
\hline Art with creativity & 10 & 4 & 8 & 2 & 4 \\
\hline Survey studies for creativity & 9 & 3 & 12 & - & - \\
\hline Personality (creative) & 3 & 1 & 3 & 1 & - \\
\hline $\begin{array}{l}\text { Experimental studies for } \\
\text { creativity }\end{array}$ & 6 & 1 & 7 & - & - \\
\hline Creativity in education & 2 & 1 & 1 & 2 & - \\
\hline Creativity tests & 12 & 2 & 12 & 2 & - \\
\hline Definition of creativity & 7 & 1 & 4 & 3 & 1 \\
\hline Components of creativity & 8 & 1 & 4 & 3 & 2 \\
\hline Review studies for creativity & 3 & 1 & 4 & - & - \\
\hline General creativity & 2 & - & - & 2 & - \\
\hline TOTAL & 104 & 37 & 108 & 25 & 8 \\
\hline
\end{tabular}


Table 2. The inclusion/exclusion criteria regarding for the 16 categories (source: created by author)

\begin{tabular}{|c|c|c|}
\hline \multirow{9}{*}{ 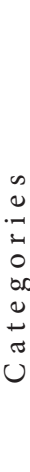 } & $\begin{array}{l}\text { The inclusion criteria: } \\
\text { direct related to search subject }\end{array}$ & $\begin{array}{l}\text { The exclusion criteria: } \\
\text { indirect related to search subject }\end{array}$ \\
\hline & - Definition of (creativity) & - Gender differences in (creativity) \\
\hline & - Components of (creativity) & - Product (creative) \\
\hline & - Art with (creativity) & - Survey studies for (creativity) \\
\hline & - Assessment of (creativity) & - Personality (creative) \\
\hline & - Measurement of (creativity) & - Experimental studies for (creativity) \\
\hline & - Criteria of (creativity) measurement & - (Creativity) in education \\
\hline & - (Creativity) tests & - Review studies for (creativity) \\
\hline & - Scoring of (creativity) measurement & - General (creativity) \\
\hline
\end{tabular}

The eight categories were classified by hierarchical method, which provides a preliminary list of concepts as relevant to the main subject (Butler \& Kline, 1998). In this method, the upper category was determined as the definition of creativity. According to this category, the other categories were determined (Figure 1). By this method, it was aimed to occur a hierarchical path from the specific to the general.

Besides, the Fisher's Exact Test (FET) was carried out to determine whether each category was taken from the sample equally. This test compares nominal variables in a category with other categories (McDonald, 2014). The FET showed that any category from the upper category to lower categories was not different significantly each other regarding the study sample. Thus, the inclusion/exclusion criteria, hierarchical method, and Fisher exact test were used respectively upon the sample before the content analysis done to the data. The conceptual analysis as one of the content analysis types was used to establish the absence and presence of concepts in the categories regarding the study sample (Writing@CSU, 2019). The content analysis was done on these eight categories (Table 3). The content analysis was also done on the criteria in terms of existing, used tests in the Creativity Tests category (Table 4).

\section{Results}

The other categories followed hierarchically creativity if the creativity term was determined as the upper category. The categories were ranked as seen in Figure 1: 1 - definition of creativity; 2 - components of creativity; 3 - art with creativity; 4 - assessment of creativity; 5 - measurement of creativity; 6 - criteria of creativity measurement; 7 - creativity tests, and 8 - scoring of creativity measurement.

The FET did not detect a significant difference among these categories (Social Science Statistics, 2019), which means that each category was taken from the literature equally as the study sample. The data was examined by content analysis in eight categories (Table 3 ). In this way, the categories were codified as presence or absence according to be represented concepts in each category (Table 3). 


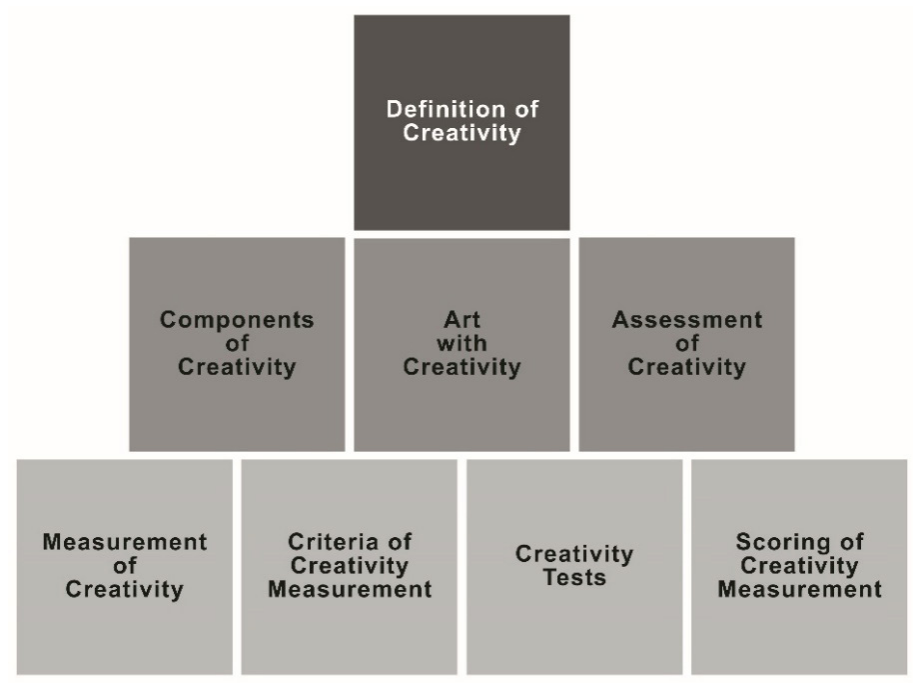

Figure 1. The classifications of the categories by hierarchical method (source: created by author)

Table 3. The content analysis regarding the eight categories (source: created by author)

\begin{tabular}{|c|c|c|c|c|c|c|c|c|}
\hline & 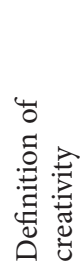 & 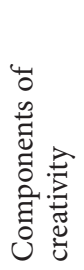 & 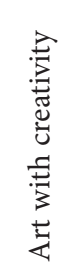 & 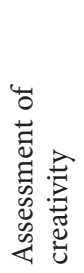 & 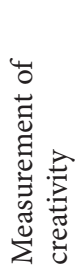 & 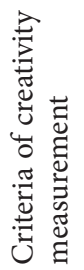 & 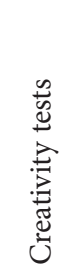 & 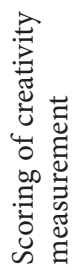 \\
\hline Absence & $\begin{array}{c}68 \\
\% 91\end{array}$ & $\begin{array}{c}67 \\
\% 89\end{array}$ & $\begin{array}{c}65 \\
\% 87\end{array}$ & $\begin{array}{c}63 \\
\% 84\end{array}$ & $\begin{array}{c}66 \\
\% 88\end{array}$ & $\begin{array}{c}63 \\
\% 84\end{array}$ & $\begin{array}{c}63 \\
\% 84\end{array}$ & $\begin{array}{c}70 \\
\% 93\end{array}$ \\
\hline Presence & $\begin{array}{c}7 \\
\% 9\end{array}$ & $\begin{array}{c}8 \\
\% 11\end{array}$ & $\begin{array}{c}10 \\
\% 13\end{array}$ & $\begin{array}{c}12 \\
\% 16\end{array}$ & $\begin{array}{c}9 \\
\% 12\end{array}$ & $\begin{array}{c}12 \\
\% 16\end{array}$ & $\begin{array}{c}12 \\
\% 16\end{array}$ & $\begin{array}{c}5 \\
\% 7\end{array}$ \\
\hline
\end{tabular}

Also, the content analysis was done on the criteria in terms of the creativity tests category, as follows: Torrance Tests of Creative Thinking (TTCT), Basadur Preference Scale (BPS), Remote Associates Test (RAT), Test for Creative Thinking-Drawing Production (TCT-DP), Wallach-Kogan Test of Creativity (WKTC), Consensual Assessment Technique (CAT), and Next Generation Creativity Survey (NGCS) (Table 4).

The most seen criteria in the tests are the originality criteria (Table 4 ). The fluency, flexibility, boundary breaking independent, unconventionality and perspective criteria come respectively after the originality (Figure 2). 
Table 4. Content analysis of the criteria regarding the used creativity tests (source: created by author)

\begin{tabular}{|c|c|c|c|c|c|c|c|c|c|}
\hline Cri & eria Tests & 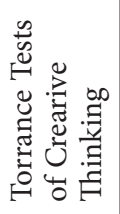 & 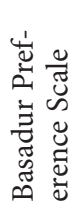 & 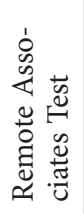 & 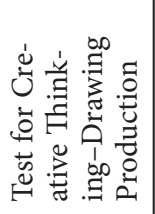 & 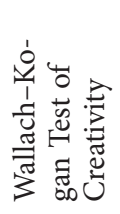 & 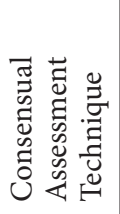 & 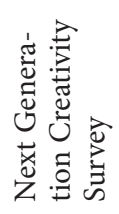 & 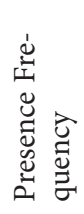 \\
\hline 1 & Fluency & + & & + & & + & & + & 4 \\
\hline 2 & Originality & + & + & + & & + & & + & 5 \\
\hline 3 & Titles & + & & & & & & & 1 \\
\hline 4 & Elaboration & + & & & & & & & 1 \\
\hline 5 & Closure & + & & & & & & & 1 \\
\hline 6 & Strengths & + & & & & & & & 1 \\
\hline 7 & Imagination & & + & & & & & & 1 \\
\hline 8 & Aesthetic appeal & & & & & & + & & 1 \\
\hline 9 & Technical skill & & & & & & + & & 1 \\
\hline 10 & Idea-generation & & + & & & & & & 1 \\
\hline 11 & Flexibility & + & & + & & & & + & 3 \\
\hline 12 & Extension & & & & + & & & & 1 \\
\hline 13 & Completion & & & & + & & & & 1 \\
\hline 14 & New elements & & & & + & & & & 1 \\
\hline 15 & Connections & & & & + & & & & 1 \\
\hline 16 & $\begin{array}{l}\text { Boundary brea- } \\
\text { king dependent }\end{array}$ & & & & + & & & & 1 \\
\hline 17 & $\begin{array}{l}\text { Boundary break- } \\
\text { ing independent }\end{array}$ & + & & & + & & & & 2 \\
\hline 18 & Perspective & + & & & + & & & & 2 \\
\hline 19 & $\begin{array}{l}\text { Humor (and } \\
\text { affectivity) }\end{array}$ & & & & + & & & & 1 \\
\hline 20 & $\begin{array}{l}\text { Uncon- } \\
\text { ventionality } \\
\text { (manipulative) }\end{array}$ & & & & + & & & & 1 \\
\hline 21 & $\begin{array}{l}\text { Uncon- } \\
\text { ventionality } \\
\text { (abstractive) }\end{array}$ & + & & & + & & & & 2 \\
\hline 22 & $\begin{array}{l}\text { Uncon- } \\
\text { ventionality } \\
\text { (symbolic) }\end{array}$ & & & & + & & & & 1 \\
\hline 23 & $\begin{array}{l}\text { Uncon- } \\
\text { ventionality } \\
\text { (using) }\end{array}$ & & & & + & & & & 1 \\
\hline 24 & Speed (time) & & & & + & & & & 1 \\
\hline 25 & Alternate uses & & & & & + & & & 1 \\
\hline
\end{tabular}

Note 1: The " + " sign indicates the presence of the related criteria in the measurement tool.

Note 2: The 25 criteria indicates the all criteria in the used the creativity tests. 


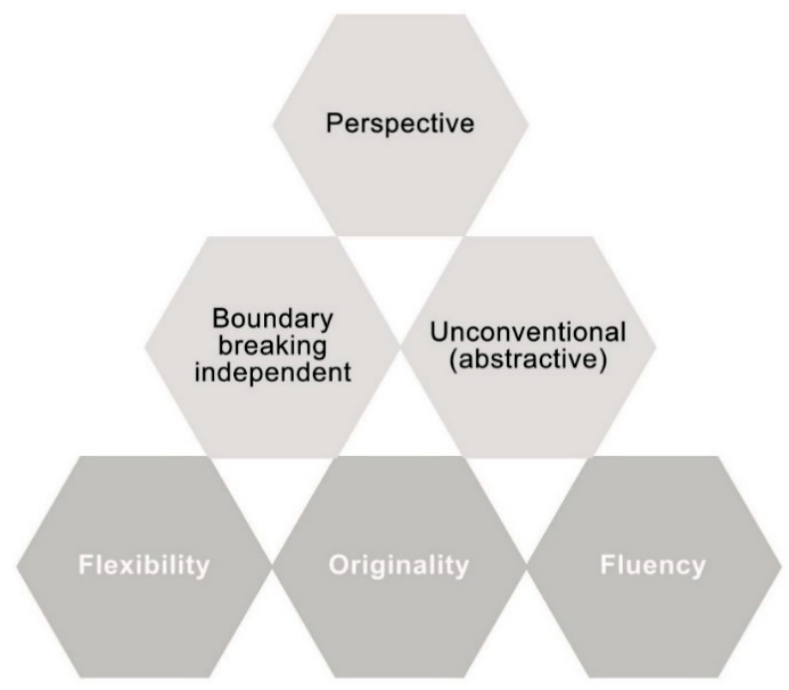

Figure 2. The most used criteria in the used creativity tests (source: created by author)

Subsequently, the (abstractness of) titles, elaboration, (resistance to premature) closure, (creative) strengths, imagination, aesthetic (aesthetic appeal), technical skill (technical execution), idea-generation, extension, completion, new elements, connections, boundary breaking dependent, humor (and affectivity), unconventionality (manipulative), unconventionality (symbolic), unconventionality (using), speed (time) and the alternate uses come equally (Table 4). It is understood that these criteria seem as common content for the creativity tests in the creativity tests category.

Afterward, the set of inclusion/exclusion criteria strategy was conducted on the rest of the criteria. According to this set, the criteria should be related to the main subject as the painting output directly, and indirectly. Thus, aesthetic appeal, technical skill, imagination, elaboration, closure, and idea-generation revealed for possible criteria of the painting output in the visual arts education.

\section{Discussion}

This study revealed that the criteria in the creativity measurement were flexibility, originality, and fluency generally (Table 4). The others were listed as the boundary-breaking independent, unconventional and the perspective respectively (Figure 2). This result is consistent with previous studies regarding the flexibility, originality, and fluency criteria (Chang et al., 2015). However, the boundary-breaking criteria were used by Urban (2005) in the TCTDP. This criterion happens when the test taker uses to extend some given figural fragments independently apart from any given fragment. The boundary-breaking criteria exhibit the risk-taking of the individual. This trait is one of the creativity components. Accordingly, boundary-breaking is the encouragement to disrupt any shape for rearranging, which is a 
creative attempt. In general, this criterion is used as a feature belonging to the drawing area and observed easily in the painting of creative individuals. Hence this criteria seems also to be appropriate for both using to predict creativity in the visual arts area and general content.

The unconventionality as the other general content represents surrealistic, fictional, abstract elements or drawings in a given fragment in the TCT-DP. This criterion is a manipulation of the material. It is a surrealistic, fictional and abstract elements or drawings (Urban, 2005). The unconventionality tends to ignore the tradition. Torrance (1966, p. 9) indicated that unconventional thinking is one of the creative attitudes. In this manner, the unconventionality seems to include a few things such as any trait which belongs to the drawing regarding the material.

The perspective criteria as another general content seen in the TCT-DP and TTCT. This criterion assesses in the drawing area as appearing of a different point of view. The perspective is a performance to move away from two-dimensionality (Urban, 2005). Although the perspective criteria are used by the general content of the creative measurement, as Nauert (2006) stated, the perspective technique is consistent with the visual arts field in the development of the painting since the Renaissance. Accordingly, the visual arts field is more related to the perspective criterion than other fields. However, originality is an important criterion as increasingly used as an inclusionary in all creativity tests without exception. According to Torrance, the production of something new as a basic takes place in all the definitions of creativity. He defined the originality as "try to think of things that no one else will think of" (Torrance, 1966, p. 15). In this way, the originality may be defined that is a rare way of thought. The used current creativity tests with their qualifications seen in Table 5.

The originality has been benefiting from aesthetic, which is used frequently in terms of artistic thinking (Acar \& Runco, 2015). Rostan, Pariser, and Gruber (2002) stated that students' aesthetic values were only improved in the visual arts education by the drawing. Therefore, the aesthetic criterion is also meaningful for the visual arts field in terms of establishing a conceptual basis to predict creativity in the painting. The aesthetic as a criterion belongs in the visual arts field. However, the aesthetic is also needed as external effectiveness in the other fields apart from the visual arts area in terms of the function (usefulness) of the product. According to Cropley (2004), some artists might be prepared to abandon "external effectiveness" (usefulness) to get "internal effectiveness" (aesthetic) in a practical setting. This expression supported in a previous study by a result that a difference found between the students (non-artists) and art students in terms of aesthetic judgment. The non-artist students judged abstraction in the painting as worthless, while the art students judged as valuable content (Kozbelt, 2006). Therefore, the aesthetic assessed in this study as specific criteria. The aesthetic as a criterion should take place in the visual arts education area to predict the creativity of students.

The aesthetic, technical skill, imagination, elaboration, closure, and idea-generation were determined for possible criteria of the creativity measurement as specific in the visual arts education regarding the painting output. According to Hennessey, Amabile, and Mueller (2011), product creativity apart from subjective judgments can be assessed by aesthetic appeal and technical goodness. At first view, technical skill seems to be related to making manual works. However, it also can be more about than this. Hennessey, Amabile, and 


\begin{tabular}{|c|c|c|c|c|c|c|c|}
\hline 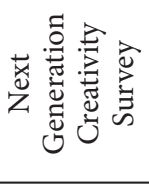 & 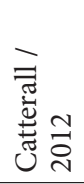 & 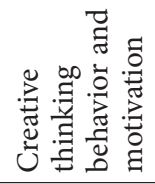 & 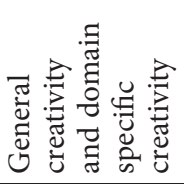 & 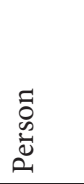 & ${ }_{3}^{0}$ & 1 & $\begin{array}{l}\bar{\pi} \\
\frac{0}{0} \\
\vec{\nu}\end{array}$ \\
\hline 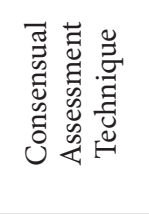 & 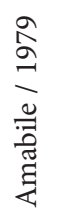 & : & 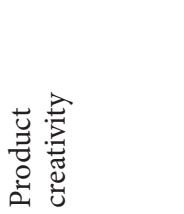 & 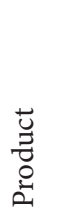 & ${ }_{3}^{0}$ & 1 & 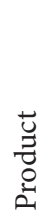 \\
\hline 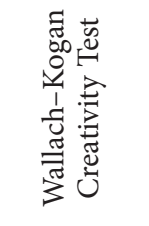 & 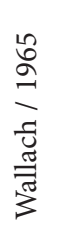 & 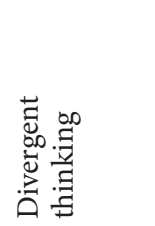 & 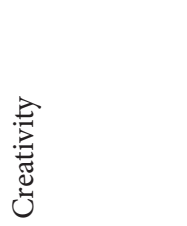 & $\begin{array}{l}\tilde{D} \\
\text { क्षे } \\
\text { م. }\end{array}$ & $\frac{\pi}{3}$ & $\underset{3}{\frac{\pi}{3}}$ & 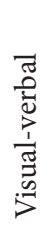 \\
\hline 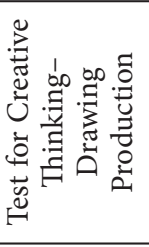 & 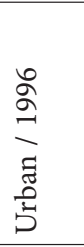 & 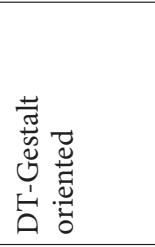 & 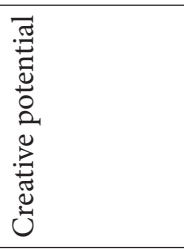 & 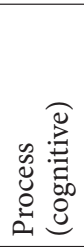 & $\overbrace{3}^{0}$ & $\frac{\pi}{3}$ & 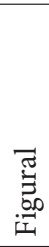 \\
\hline 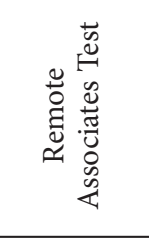 & 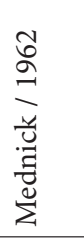 & 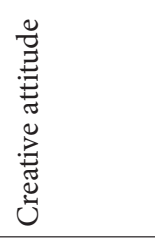 & 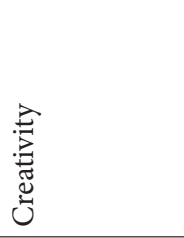 & 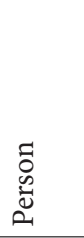 & 1 & 1 & $\begin{array}{l}\overline{0} \\
\frac{0}{0} \\
\vec{\nu}\end{array}$ \\
\hline 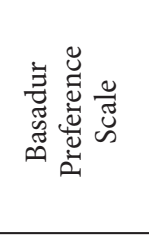 & 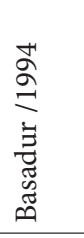 & 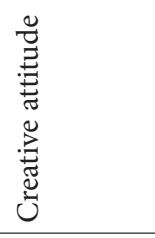 & 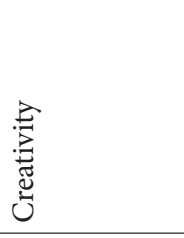 & 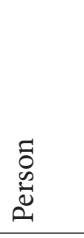 & 1 & 1 & 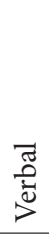 \\
\hline 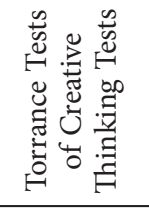 & 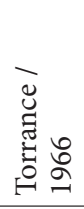 & 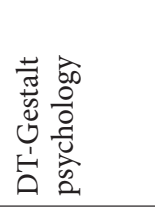 & 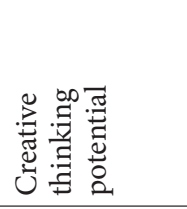 & 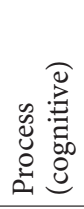 & $\frac{\pi}{3}$ & $\overbrace{0}^{*}$ & 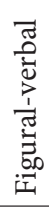 \\
\hline 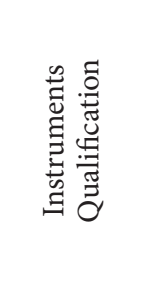 & 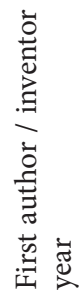 & 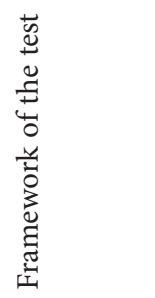 & 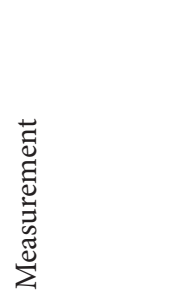 & 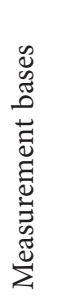 & 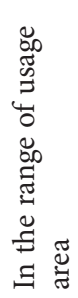 & 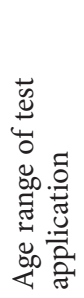 & 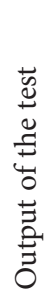 \\
\hline
\end{tabular}


Mueller (2011) found a strong correlation between technical goodness and the completion of the products. In the CAT, technical skill possesses an unlimited scope to visualize as activities of designing, drawing, and manipulating images in mind as spatial-visual creativity (Kerr \& McKay, 2013). For example, Rostan (2005) found that experienced art students had higher scores on technical skill and creativity than novice art students. In other studies, art students had higher scores on technical skills than non-art students did (Chan \& Zhao, 2010; Rostan et al., 2002). These results indicate that students' technical skills can be related to the visual arts area regarding the painting more than other fields. However, the aesthetic appeal and technical goodness were also in the CAT in terms of the general content criteria. In this manner, Hennessey, Amabile, and Mueller (2011) claimed that the CAT helps the understanding of creativity. Thus, the aesthetic and technical skills can be determined to predict creativity both for the specific criterion and general criterion.

The imagination as the other specific criterion is related to new meanings of producing creative thinking (Ho et al., 2013). The creativity fed from the imagination (e.g., Runco, 2007). The imagination can be a unique way to create new things such as the original. Although imagination starts in the cognitive process at first, it can exhibit itself easily in visual forms such as painting or drawing. As Rostan (1997) reported, free-drawing (from imagination) is more correlated with novelty than the life-drawing (from any scene seen before). Although the imagination stands up closer to the visual arts area, it has been used in the BPS as the creativity measurement as the general content. The imagination allows the ideation boundless as it happened in brainstorming (Basadur \& Finkbeiner, 1985). It can be said that the imagination is infinite thinking as logical or illogical, provides a contribution to the creativity in terms of a great variety of ways. Therefore, the imagination is a criterion that can be used in both a specific content domain and general content domain to predict creativity.

In a previous study (Ülger, 2016), a significant correlation was found between students' technical skills and elaboration skills exhibited in their paintings. This result supports that the elaboration criteria can be used to predict creativity in the painting. However, the elaboration is only used in the TTCT as general content. The elaboration is to add ideas to an object or a picture throughout the drawing to make it tell us interesting a story as possible (Torrance, 1966). According to Csikszentmihalyi (2013), the elaboration criteria is a necessary criteria on whether an artwork is creative or not. Although the elaboration used in the general content, it should be considered in the visual arts area as the specific content criteria to predict creativity in the painting.

The closure as other specific criteria is the ability to maintain openness as a long through investigating (e.g., Kim, 2011), and remaining open to uncertainty (Chávez-Eakle et al., 2012) for individuals. In this manner, the closure means as thinking without depending on any fixed idea. However, there are some disadvantages for individuals to remain this uncertainty (Basadur, 1994). Whereas, the uncertainty is essential for creativity (Sternberg, 2003). Independent thinking from any fixed idea is open-ended thinking, which keeps the uncertainty. The openness as a bridge between art and creative thinking (Ulger, 2016), it should be predicted in the arts (Barry Kaufman et al., 2016). Kay (1994) found that creative artists consumed more time to complete a drawing task than less creative artists. That is, the closure is shown in the extension of the uncertainty. Accordingly, the closure is a necessary criterion 
to predict creativity in the painting. From this perspective, the closure as a specific content domain can be in the painting like imagination, aesthetic, and technical skill.

Numerous scholars stated that challenging, broadening and innovation are important traits to predict creativity (Epstein et al., 2008; Runco, 2016). The other scholars also emphasized the importance of the idea generation in the prediction of creativity (Almeida et al., 2008; Clapham et al., 2005; Ho et al., 2013). In general, divergent thinking tests for creativity measurement contain idea generation (Reiter-Palmon et al., 2019). Also, Basadur and Finkbeiner (1985, p. 38) underlined that the idea generation is a trait of creativity as imaginative and divergent thinking. Also, the imagination supports both the originality and idea generation (Ho et al., 2013). The idea generation can be closer as related to the specific content criteria for the visual arts field when considered interrelated traits of the challenging, broadening, innovation, originality and imagination.

Some of the creativity tests as the TTCT, TCT-DP, and WKTC are more related to the visuality predominantly in terms of either figure or drawing forms (Table 5) than the others such as BPS, RAT, and the NGCS. Whereas, visuality is very important to predict creativity, especially the child's painting. On the other hand, although the creativity test judgments (e.g., scoring) appear to vary broadly, responses are commonly scored for fluency, flexibility, and originality which are just prominent traits among the many processes (Reiter-Palmon et al., 2019). In this study, common criteria were identified to predict creativity as the flexibility, originality, fluency, boundary breaking independent, unconventional, and perspective. Besides that, the aesthetic, technical skill, imagination, elaboration, closure, and idea generation were recognized as the specific criteria for the visual arts field to predict creativity in the painting. In a previous study, it was found different traits of creativity skills in persons in various domains such as music, visual arts, creative writing, science, and technology areas. However, personal traits were also observed changeability in different domains (Hong et al., 2014). This result indicates that a holistic approach to predict the creative skills of individuals can be possible as a combination of the specific and general content criteria to predict creativity in an inclusive format (Figure 3). Creative work is made possible in a domain. Also, creativity is limitless to any domain. However, creativity is influenced by other domains at least in the final product in terms of the creative process. In a study on how different domains effect on creativity, cross-domains were found to be prevalent. So, as a ubiquitous component of the creative process, different domains support creative tasks (Scotney et al., 2019).

However, according to Cropley (2004), a creativity test could be improved in a specific domain by comparing some traits. Such a test with including appropriate criteria, it can help students to reveal their creative skills. Therefore, the requirements of the criteria to predict creativity need to be debated to qualify properly under the frame of the domain. The scholars (Lindström, 2006; McKay et al., 2017) suggest further study to conduct in the future for the specific measurement of creativity for various fields.

\section{Limitations and implications}

The publications published between 2000 and the first quarter of 2018s was the limitation of this study. Therefore, the result of this study was dependent on the content analysis of the 


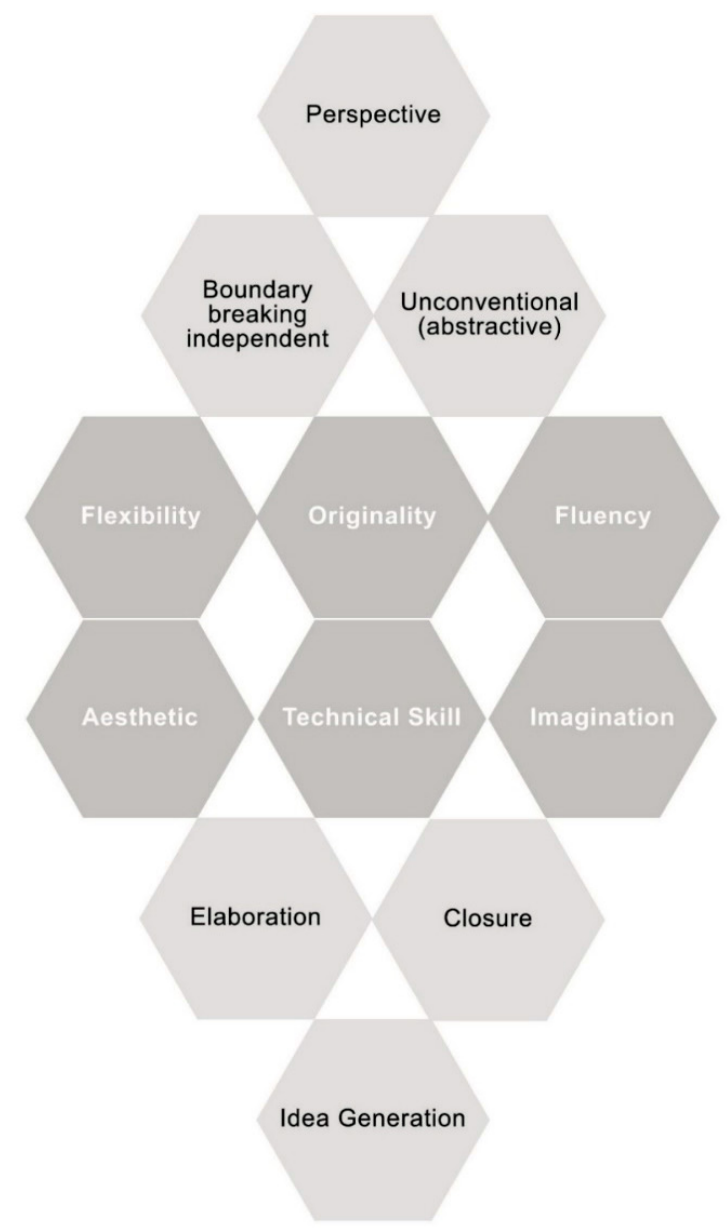

Figure 3. The combination of the criteria in terms of overall creativity measurement (source: created by author)

seven creativity tests in the creativity tests category of the study sample. However, this study was the first to attempt a searching of the priorities as the criteria to predict creativity in the visual arts education. As an implication, this study indicated that a student's creativity in any field could be predicted based on the specific criteria.

\section{Conclusions}

This study aimed to predict creativity in the painting of students in visual arts education. With this purpose, this study reviewed the literature to predict creativity in this education discipline. Despite the creativity skill is vital for visual arts students, this education discipline has lacked any criteria in the creativity prediction. By this study, some priority criteria (aesthetic, technical skill, imagination, elaboration, closure, and idea generation) revealed to 
predict creativity in the painting. Also, the flexibility, originality, fluency, boundary breaking independent, unconventional, and perspective were the universal criteria for the general content of creativity. Reiter-Palmon, Forthmann, and Barbot (2019) stated that creativity tests generally include common criteria such as fluency, flexibility, and originality, which are just one dimension among many dimensions. Whereas, scholars suggest that the measure of creativity as the predictors may be specific. The possible scoring criteria to predict the creativity revealed by this study in visual arts education as a specific domain, which leads future research. Finally, this study was an initial step for searching for a common ground for the criteria to predict creativity in the paintings of the visual arts education students. Therefore, future studies should be conducted on the measurement of creativity in the painting for the development of a tool, to predict the creativity skills of the students.

\section{References}

Acar, S., \& Runco, M. A. (2015). Thinking in multiple directions: hyperspace categories in divergent thinking. Psychology of Aesthetics, Creativity, and the Arts, 9(1), 41-53. https://doi.org/10.1037/a0038501

Almeida, L. S., Prieto Prieto, L., Ferrando, M., Oliveira, E., \& Ferrándiz, C. (2008). Torrance test of creative thinking: the question of its construct validity. Thinking Skills and Creativity, 3(1), 53-58. https://doi.org/10.1016/j.tsc.2008.03.003

Alter, F. (2010). Using the visual arts to harness creativity. UNESCO Observatory, Faculty of Architecture, Building and Planning, the University of Melbourne Refereed E-Journal, 1(5). https://pdfs.semanticscholar.org/319a/592fc933573c004cb987f5e3da445a11feb3.pdf

Barry Kaufman, S., Quilty, L. C., Grazioplene, R. G., Hirsh, J. B., Gray, J. R., Peterson, J. B., \& DeYoung, C. G. (2016). Openness to experience and intellect differentially predict creative achievement in the arts and sciences. Journal of Personality, 84(2), 248-258. https://doi.org/10.1111/jopy.12156

Basadur, M. (1994). Managing the creative process in organizations. In M. A. Runco (Ed.), Problem finding, problem solving, and creativity (pp. 237-268). Ablex Publishing Corporation.

Basadur, M., \& Finkbeiner, C. T. (1985). Measuring preference for ideation in creative problem-solving training. The Journal of Applied Behavioral Science, 21(1), 37-49. https://doi.org/10.1177/002188638502100104

Batey, M. (2012). The measurement of creativity: from definitional consensus to the introduction of a New Heuristic framework. Creativity Research Journal, 24(1), 55-65. https://doi.org/10.1080/10400419.2012.649181

Boise State University. (2019). Research compliance. https://www.boisestate.edu/research-compliance/

Broome, J. (2016). Assessing the professional development needs of arts instructors working in multiage classrooms. Arts Education Policy Review, 117(1), 65-72.

https://doi.org/10.1080/10632913.2016.1107395

Butler, D. L., \& Kline, M. A. (1998). Good versus creative solutions: a comparison of brainstorming, hierarchical, and perspective-changing heuristics. Creativity Research Journal, 11(4), 325-331. https://doi.org/10.1207/s15326934crj1104_6

Chan, D. W., \& Zhao, Y. (2010). The relationship between drawing skill and artistic creativity: do age and artistic involvement make a difference? Creativity Research Journal, 22(1), 27-36. https://doi.org/10.1080/10400410903579528 
Chang, Y., Li, B.-D., Chen, H.-Ch., \& Chiu, F.-Ch. (2015). Investigating the synergy of critical thinking and creative thinking in the course of integrated activity in Taiwan. Educational Psychology: An International Journal of Experimental Educational Psychology, 35(3), 341-360. https://doi.org/10.1080/01443410.2014.920079

Chávez-Eakle, R. A., Eakle, A. J., \& Cruz-Fuentes, C. (2012). The multiple relations between creativity and personality. Creativity Research Journal, 24(1), 76-82. https://doi.org/10.1080/10400419.2012.649233

Clapham, M. M. (2004). The convergent validity of the Torrance tests of creative thinking and creativity interest inventories. Educational and Psychological Measurement, 64(5), 828-841. https://doi.org/10.1177/0013164404263883

Clapham, M. M., Cowdery, E. M., King, K. E., \& Montang, M. A. (2005). Predicting work activities with divergent thinking tests: a longitudinal study. Journal of Creative Behavior, 39(3), 149-166. https://doi.org/10.1002/j.2162-6057.2005.tb01256.x

Cropley, A. J. (2004). Creativity in education and learning: a guide for teachers and educators. Routledge.

Csikszentmihalyi, M. (2013). Creativity: flow and the psychology of discovery and invention. HarperCollins Publishers.

Diket, R. M., \& Brewer, Th. M. (2011). NAEP and policy: chasing the tail of the assessment tiger. Arts Education Policy Review, 112(1), 35-47. https://doi.org/10.1080/10632913.2011.518126

Epstein, R., Schmidt, S. M., \& Warfel, R. (2008). Measuring and training creativity competencies: validation of a new test. Creativity Research Journal, 20(1), 7-12. https://doi.org/10.1080/10400410701839876

Fink, A., \& Benedek, M. (2013). The creative brain: brain correlates underlying the generation of original ideas. In O. Vartanian, A. S. Bristol, \& J. C. Kaufman (Eds.), Neuroscience of creativity (pp. 207232). The MIT Press. https://doi.org/10.7551/mitpress/9780262019583.003.0010

Garg, R. (2016). Methodology for research I. Indian Journal of Anaesthesia, 60(9), 640-645. https://doi.org/10.4103/0019-5049.190619

Hallam, J. L., Hewitt, D., \& Buxton, S. (2014). An exploration of children's experiences of art in the classroom. The International Journal of Art and Design Education, 33(2), 195-207. https://doi.org/10.1111/j.1476-8070.2014.12022.x

Hennessey, B. A., Amabile, T. M., \& Mueller, J. S. (2011). Consensual assessment. In M. A. Runco \& S. R. Pritzker (Eds.-in-Chief), Encyclopedia of Creativity, 1, 253-260. Academic Press. https://doi.org/10.1016/B978-0-12-375038-9.00046-7

Ho, H.-Ch., Wang, Ch.-Ch., \& Cheng, Y.-Y. (2013). Analysis of the scientific imagination process. Thinking Skills and Creativity, 10, 68-78. https://doi.org/10.1016/j.tsc.2013.04.003

Hokanson, B., \& McCluske, M. (2016). The creativity habit. In E. Boling, R. A. Schwier, C. M. Gray, K. M. Smith, \& K. Campbell (Eds.), Studio teaching in higher education: selected design cases (pp. 180-194). Routledge.

Hong, E., Peng, Y., \& O’Neil, Jr. H. F. (2014). Activities and accomplishments in various domains: relationships with creative personality and creative motivation in adolescence. Roeper Review, 36(2), 92-103. https://doi.org/10.1080/02783193.2014.884199

Irish National Teachers' Organization. (2019). Publications. https://www.into.ie/media-centre/ publications/\#top

Jolley, R. (2019). The importance of an art education,. Research and Analysis: AQA. https://research.aqa. org.uk/perspectives/importance-art-education

Kay, S. (1994). A method for investigating the creative thought process. In M. A. Runco (Ed.), Problem finding, problem solving, and creativity (pp. 116-129). Ablex Publishing Corporation.

Kerr, B., \& McKay, R. (2013). Searching for tomorrow's innovators: profiling creative adolescents. Creativity Research Journal, 25(1), 21-32. https://doi.org/10.1080/10400419.2013.752180 
Kim, K. H. (2011). The creativity crisis: the decrease in creative thinking scores on the torrance tests of creative thinking. Creativity Research Journal, 23(4), 285-295.

https://doi.org/10.1080/10400419.2011.627805

Kozbelt, A. (2006). Dynamic evaluation of Matisse's 1935. Large Reclining Nude, Empirical Studies of the Arts, 24(2), 119-137. https://doi.org/10.2190/A2VY-TEBW-VH45-285E

Lindström, L. (2006). Creativity: what is it? Can you assess it? Can it be taught? The International Journal of Art and Design Education, 25(1), 53-66. https://doi.org/10.1111/j.1476-8070.2006.00468.x

Mannathoko, M. C., \& Mamvuto, A. (2018). Learner involvement in art and design education assessment: the missing matrix in Botswana's primary schools. Arts Education Policy Review, 119(3), 172-184. https://doi.org/10.1080/10632913.2016.1260081

McDonald, J. H. (2014). Handbook of biological statistics. Sparky House Publishing.

McKay, A. S., Karwowski, M., \& Kaufman, J. C. (2017). Measuring the muses: validating the Kaufman Domains of Creativity Scale (K-DOCS). Psychology of Aesthetics, Creativity, and the Arts, 11(2), 216-230. https://doi.org/10.1037/aca0000074

Nauert, Ch. G. (2006). Humanism and the culture of Renaissance Europe. Series: New Approaches to European History. Cambridge University Press. https://doi.org/10.1017/CBO9780511808388

Plucker, J. A., \& Makel, M. C. (2010). Assessment of creativity. In J. C. Kaufman \& R. J. Sternberg (Eds.), The Cambridge Handbook of Creativity (pp. 48-73). Cambridge University Press. https://doi.org/10.1017/CBO9780511763205.005

Reiter-Palmon, R., Forthmann, B., \& Barbot, B. (2019). Scoring divergent thinking tests: a review and systematic framework. Psychology of Aesthetics, Creativity, and the Arts, 13(2), 144-152. https://doi.org/10.1037/aca0000227

Rostan, S. M. (1997). A study of young artists: the development of artistic talent and creativity. Creative Research Journal, 10(2-3), 175-192. https://doi.org/10.1207/s15326934crj1002\&3_6

Rostan, S. M. (2005). Educational intervention and the development of young art students' talent and creativity. Journal of Creative Behavior, 39(4), 237-261. https://doi.org/10.1002/j.2162-6057.2005.tb01260.x

Rostan, S. M., Pariser, D., \& Gruber, H. E. (2002). A cross-cultural study of the development of artistic talent, creativity and giftedness. High Ability Studies, 13(2), 125-155. https://doi.org/10.1080/1359813022000048789

Runco, M. A. (2016). Creative interpretations of educational contradictions. In R. A. Beghetto \& B. Sriraman (Eds.), Creative contradictions in education: cross disciplinary paradoxes and perspectives (pp. 75-87). Series: Creativity Theory and Action in Education. Vol. 1. Springer. https://doi.org/10.1007/978-3-319-21924-0_5

Runco, M. A. (2007). Creativity. Theories and themes: research, development, and practice. Elsevier Academic Press.

Sabol, F. R. (2004). The assessment context: part two. Arts Education Policy Review, 105(4), 3-8. https://doi.org/10.3200/AEPR.105.4.3-8

Schultz, R. A. (2002). Apples, oranges, and assessment. Arts Education Policy Review, 103(3), 11-16. https://doi.org/10.1080/10632910209600289

Scotney, V. S., Weissmeyer, S., Carber, N., \& Gabora, L. (2019). The ubiquity of cross-domain thinking in the early phase of the creative process. Frontiers in Psychology, 10. https://www.frontiersin.org/articles/10.3389/fpsyg.2019.01426/full

Social Science Statistics. (2019). Easy fisher exact test calculator. https://www.socscistatistics.com/tests/ fisher/default2.aspx

Sternberg, R. J. (2003). Creative thinking in the classroom. Scandinavian Journal of Educational Research, 47(3), 325-338. https://doi.org/10.1080/00313830308595 
Torrance, E. P. (1966). Torrance tests of creative thinking. Personnel Press.

Ulger, K. (2016). The creative training in the visual arts education. Thinking Skills and Creativity, 19, 73-87. https://doi.org/10.1016/j.tsc.2015.10.007

Ulger, K. (2015). The structure of creative thinking: visual and verbal areas. Creativity Research Journal, 27(1), 102-106. https://doi.org/10.1080/10400419.2015.992689

United Nations Educational, Scientific and Cultural Organization. (2006, 6-9 March). Road map for arts education. The World Conference on Arts Education: Building Creative Capacities for the 21st Century. http://www.unesco.org/new/fileadmin/MULTIMEDIA/HQ/CLT/CLT/pdf/Arts_Edu_ RoadMap_en.pdf

Urban, K. K. (2005). Assessing creativity: The Test for Creative Thinking-Drawing Production (TCTDP). International Education Journal, 6(2), 272-280.

Ülger, K. (2016). Öğrencilerin resim yapma becerilerinde gözlemlenen yaratıcılık ile yaratıcı düşünme becerileri arasındaki ilişki. Abant İzzet Baysal Üniversitesi Eğitim Fakültesi Dergisi, 16(4), 2023-2039.

Viskontas, I. V., \& Miller, B. L. (2013). Art and dementia: how degeneration of some brain regions can lead to new creative impulses. In O. Vartanian, A. S. Bristol, \& J. C. Kaufman, (Eds.), Neuroscience of creativity (pp. 115-132). The MIT Press. https://doi.org/10.7551/mitpress/9780262019583.003.0006

Weinstein, E. C., Clark, Z., DiBartolomeo, D. J., \& Davis, K. (2014). A decline in creativity? It depends on the domain. Creativity Research Journal, 26(2), 174-184.

https://doi.org/10.1080/10400419.2014.901082

Writing@CSU. (2019). Types of content analysis. https://writing.colostate.edu/guides/page. $\mathrm{cfm}$ ?pageid $=1308$ \&guideid $=61$

Zaidel, D. W. (2013). Biological and neuronal underpinnings of creativity in the arts. In O. Vartanian, A. S. Bristol, \& J. C. Kaufman (Eds.), Neuroscience of creativity (pp. 133-148). The MIT Press. https://doi.org/10.7551/mitpress/9780262019583.003.0007

\section{Appendix. The list of the publications as related to main subject directly}

\begin{tabular}{|l|l|l|l|l|}
\hline First author & Year & \multicolumn{1}{|c|}{ Publication title } & $\begin{array}{l}\text { Journal and book or } \\
\text { conference paper }\end{array}$ & $\begin{array}{l}\text { The reviewed } \\
\text { content under } \\
\text { the title of the } \\
\text { categories }\end{array}$ \\
\hline Acar, Selcuk & 2014 & $\begin{array}{l}\text { "Assessing Associative Distance } \\
\text { Among Ideas Elicited by Tests of } \\
\text { Divergent Thinking" }\end{array}$ & $\begin{array}{l}\text { Creativity Research } \\
\text { Journal }\end{array}$ & $\begin{array}{l}\text { Assessment of } \\
\text { creativity }\end{array}$ \\
\hline Acar, Selcuk & 2015 & $\begin{array}{l}\text { "Thinking in Multiple Directions: } \\
\text { Hyperspace Categories in } \\
\text { Divergent Thinking" }\end{array}$ & $\begin{array}{l}\text { Psychology of } \\
\text { Aesthetics, Creativity, } \\
\text { and the Arts }\end{array}$ & $\begin{array}{l}\text { Measurement of } \\
\text { creativity }\end{array}$ \\
\hline Acar, Selcuk & 2017 & $\begin{array}{l}\text { "Ingredients of Creativity: } \\
\text { Originality and More" }\end{array}$ & $\begin{array}{l}\text { Creativity Research } \\
\text { Journal }\end{array}$ & $\begin{array}{l}\text { Components of } \\
\text { creativity }\end{array}$ \\
\hline $\begin{array}{l}\text { Almeida, } \\
\text { Leandro S. }\end{array}$ & 2008 & $\begin{array}{l}\text { "Torrance Test of Creative } \\
\text { Thinking: The Question of Its } \\
\text { Construct Validity" }\end{array}$ & $\begin{array}{l}\text { Thinking Skills and } \\
\text { Creativity }\end{array}$ & $\begin{array}{l}\text { Assessment of } \\
\text { creativity }\end{array}$ \\
\hline Alter, Frances & 2009 & $\begin{array}{l}\text { "Understanding the Role of } \\
\text { Critical and Creative Thinking in } \\
\text { Australian Primary School Visual } \\
\text { Arts Education" }\end{array}$ & $\begin{array}{l}\text { International Art } \\
\text { in Early Childhood } \\
\text { Research Journal }\end{array}$ & $\begin{array}{l}\text { Art with } \\
\text { creativity }\end{array}$ \\
\hline
\end{tabular}


Continued Appendix

\begin{tabular}{|c|c|c|c|c|}
\hline First author & Year & Publication title & $\begin{array}{l}\text { Journal and book or } \\
\text { conference paper }\end{array}$ & $\begin{array}{l}\text { The reviewed } \\
\text { content under } \\
\text { the title of the } \\
\text { categories }\end{array}$ \\
\hline Alter, Frances & 2010 & $\begin{array}{l}\text { "Using the Visual Arts to Harness } \\
\text { Creativity" }\end{array}$ & $\begin{array}{l}\text { Multi-disciplinary } \\
\text { journal in the arts }\end{array}$ & $\begin{array}{l}\text { Art with } \\
\text { creativity }\end{array}$ \\
\hline $\begin{array}{l}\text { Atkinson, } \\
\text { Dennis }\end{array}$ & 2006 & $\begin{array}{l}\text { "School Art Education: Mourning } \\
\text { the Past and Opening a Future" }\end{array}$ & $\begin{array}{l}\text { The International } \\
\text { Journal of Art and } \\
\text { Design Education }\end{array}$ & $\begin{array}{l}\text { Criteria of } \\
\text { creativity } \\
\text { measurement }\end{array}$ \\
\hline Baer, John & 1994 & $\begin{array}{l}\text { "Reply / Why You Still Shouldn't } \\
\text { Trust Creativity Tests" }\end{array}$ & $\begin{array}{l}\text { Educational } \\
\text { Leadership }\end{array}$ & $\begin{array}{l}\text { Measurement of } \\
\text { creativity }\end{array}$ \\
\hline Batey, Mark & 2012 & $\begin{array}{l}\text { "The Measurement of Creativity: } \\
\text { From Definitional Consensus } \\
\text { to the Introduction of a New } \\
\text { Heuristic Framework" }\end{array}$ & $\begin{array}{l}\text { Creativity Research } \\
\text { Journal }\end{array}$ & $\begin{array}{l}\text { Measurement of } \\
\text { creativity }\end{array}$ \\
\hline $\begin{array}{l}\text { Beketayev, } \\
\text { Kenes }\end{array}$ & 2016 & $\begin{array}{l}\text { "Scoring Divergent Thinking Tests } \\
\text { by Computer with a Semantics- } \\
\text { Based Algorithm" }\end{array}$ & $\begin{array}{l}\text { Europe's Journal of } \\
\text { Psychology }\end{array}$ & $\begin{array}{l}\text { Scoring of } \\
\text { creativity } \\
\text { measurement } \\
\end{array}$ \\
\hline $\begin{array}{l}\text { Boden, } \\
\text { Margaret A. }\end{array}$ & 2013 & $\begin{array}{l}\text { "Creativity as a Neuroscientific } \\
\text { Mystery" }\end{array}$ & $\begin{array}{l}\text { Neuroscience of } \\
\text { Creativity }\end{array}$ & $\begin{array}{l}\text { Components of } \\
\text { creativity }\end{array}$ \\
\hline $\begin{array}{l}\text { Carson, } \\
\text { Shelley H. }\end{array}$ & 2005 & $\begin{array}{l}\text { "Reliability, Validity, and Factor } \\
\text { Structure of the Creative } \\
\text { Achievement Questionnaire" }\end{array}$ & $\begin{array}{l}\text { Creativity Research } \\
\text { Journal }\end{array}$ & Creativity tests \\
\hline $\begin{array}{l}\text { Chan, David } \\
\text { W. }\end{array}$ & 2010 & $\begin{array}{l}\text { "The Relationship Between } \\
\text { Drawing Skill and Artistic } \\
\text { Creativity: Do Age and Artistic } \\
\text { Involvement Make a Difference?" }\end{array}$ & $\begin{array}{l}\text { Creativity Research } \\
\text { Journal }\end{array}$ & $\begin{array}{l}\text { Assessment of } \\
\text { creativity }\end{array}$ \\
\hline $\begin{array}{l}\text { Clapham, } \\
\text { Maria M. }\end{array}$ & 2004 & $\begin{array}{l}\text { "The Convergent Validity of } \\
\text { the Torrance Tests of Creative } \\
\text { Thinking and Creativity Interest } \\
\text { Inventories" }\end{array}$ & $\begin{array}{l}\text { Educational and } \\
\text { Psychological } \\
\text { Measurement }\end{array}$ & Creativity tests \\
\hline Clarke, Angela & 2012 & $\begin{array}{l}\text { "Fostering Creativity: A } \\
\text { Multiple Intelligences Approach } \\
\text { to Designing Learning in } \\
\text { Undergraduate Fine Art" }\end{array}$ & $\begin{array}{l}\text { The International } \\
\text { Journal of Art and } \\
\text { Design Education }\end{array}$ & $\begin{array}{l}\text { Definition of } \\
\text { creativity }\end{array}$ \\
\hline $\begin{array}{l}\text { Cramond, } \\
\text { Bonnie }\end{array}$ & 2005 & $\begin{array}{l}\text { "A Report on the } 40 \text {-Year Follow- } \\
\text { Up of the Torrance Tests of } \\
\text { Creative Thinking: Alive and Well } \\
\text { in the New Millennial" }\end{array}$ & $\begin{array}{l}\text { Gifted Child } \\
\text { Quarterly }\end{array}$ & $\begin{array}{l}\text { Assessment of } \\
\text { creativity }\end{array}$ \\
\hline $\begin{array}{l}\text { Cropley, } \\
\text { Arthur J. }\end{array}$ & 2000 & $\begin{array}{l}\text { "Defining and Measuring } \\
\text { Creativity: Are Creativity Tests } \\
\text { Worth Using?" }\end{array}$ & Roeper Review & $\begin{array}{l}\text { Measurement of } \\
\text { creativity }\end{array}$ \\
\hline $\begin{array}{l}\text { Diket, Read } \\
\text { M. }\end{array}$ & 2011 & $\begin{array}{l}\text { "NAEP and Policy: Chasing the } \\
\text { Tail of the Assessment Tiger" }\end{array}$ & $\begin{array}{l}\text { Arts Education Policy } \\
\text { Review }\end{array}$ & $\begin{array}{l}\text { Assessment of } \\
\text { creativity }\end{array}$ \\
\hline Dumas, Denis & 2014 & $\begin{array}{l}\text { "Understanding Fluency and } \\
\text { Originality: A Latent Variable } \\
\text { Perspective" }\end{array}$ & $\begin{array}{l}\text { Thinking Skills and } \\
\text { Creativity }\end{array}$ & \begin{tabular}{|l|} 
Criteria of \\
creativity \\
measurement
\end{tabular} \\
\hline
\end{tabular}


Continued Appendix

\begin{tabular}{|c|c|c|c|c|}
\hline First author & Year & Publication title & $\begin{array}{l}\text { Journal and book or } \\
\text { conference paper }\end{array}$ & $\begin{array}{l}\text { The reviewed } \\
\text { content under } \\
\text { the title of the } \\
\text { categories }\end{array}$ \\
\hline Fink, Andreas & 2013 & $\begin{array}{l}\text { "The Creative Brain: Brain } \\
\text { Correlates Underlying the } \\
\text { Generation of Original Ideas" }\end{array}$ & $\begin{array}{l}\text { Neuroscience of } \\
\text { Creativity }\end{array}$ & $\begin{array}{l}\text { Criteria of } \\
\text { creativity } \\
\text { measurement } \\
\end{array}$ \\
\hline Fleming, Mike & 2010 & $\begin{array}{l}\text { Arts in Education and Creativity: } \\
\text { A Literature Review }\end{array}$ & $\begin{array}{l}\text { Creativity, Culture } \\
\text { and Education Series }\end{array}$ & $\begin{array}{l}\text { Art with } \\
\text { creativity }\end{array}$ \\
\hline $\begin{array}{l}\text { Fuchs Holzer, } \\
\text { Madeleine }\end{array}$ & 2009 & $\begin{array}{l}\text { "The Arts and Elementary } \\
\text { Education: Shifting the Paradigm" }\end{array}$ & $\begin{array}{l}\text { Teachers and } \\
\text { Teaching: Theory and } \\
\text { Practice }\end{array}$ & $\begin{array}{l}\text { Art with } \\
\text { creativity }\end{array}$ \\
\hline Giloi, Susan & 2013 & $\begin{array}{l}\text { "Current Approaches to the } \\
\text { Assessment of Graphic Design in } \\
\text { a Higher Education Context" }\end{array}$ & $\begin{array}{l}\text { The International } \\
\text { Journal of Art and } \\
\text { Design Education }\end{array}$ & $\begin{array}{l}\text { Assessment of } \\
\text { creativity }\end{array}$ \\
\hline $\begin{array}{l}\text { Guilford, Joy } \\
\text { Paul }\end{array}$ & 1971 & The Analysis of Intelligence & $\begin{array}{l}\text { McGraw-Hill Series } \\
\text { in Psychology }\end{array}$ & $\begin{array}{l}\text { Criteria of } \\
\text { creativity } \\
\text { measurement }\end{array}$ \\
\hline Hao, Ning & 2016 & $\begin{array}{l}\text { "A New Tool to Measure } \\
\text { Malevolent Creativity: The } \\
\text { Malevolent Creativity Behavior } \\
\text { Scale" }\end{array}$ & $\begin{array}{l}\text { Frontiers in } \\
\text { Psychology }\end{array}$ & $\begin{array}{l}\text { Scoring of } \\
\text { creativity } \\
\text { measurement }\end{array}$ \\
\hline Ho, Hsiao-Chi & 2013 & $\begin{array}{l}\text { "Analysis of the Scientific } \\
\text { Imagination Process" }\end{array}$ & $\begin{array}{l}\text { Thinking Skills and } \\
\text { Creativity }\end{array}$ & $\begin{array}{l}\text { Criteria of } \\
\text { creativity } \\
\text { measurement }\end{array}$ \\
\hline $\begin{array}{l}\text { Howell, } \\
\text { Cynthia } \\
\text { Grenko, } \\
\text { Dolares }\end{array}$ & 1990 & $\begin{array}{l}\text { "The Relationship Between Arts } \\
\text { Education and Creativity Among } \\
\text { High School Students" }\end{array}$ & $\begin{array}{l}\text { http://media. } \\
\text { proquest.com/ }\end{array}$ & $\begin{array}{l}\text { Assessment of } \\
\text { creativity }\end{array}$ \\
\hline Humble, Steve & 2018 & $\begin{array}{l}\text { "Factor Structure of the Torrance } \\
\text { Tests of Creative Thinking Figural } \\
\text { Form A in Kiswahili Speaking } \\
\text { Children: Multidimensionality } \\
\text { and Influences on Creative } \\
\text { Behavior" }\end{array}$ & $\begin{array}{l}\text { Thinking Skills and } \\
\text { Creativity }\end{array}$ & $\begin{array}{l}\text { Measurement of } \\
\text { creativity }\end{array}$ \\
\hline $\begin{array}{l}\text { Ibérico } \\
\text { Nogueira, Sara }\end{array}$ & 2017 & $\begin{array}{l}\text { "Two Tracks of Thought: A } \\
\text { Structural Model of the } \\
\text { Test for Creative Thinking- } \\
\text { Drawing Production } \\
\text { (TCT-DP)" }\end{array}$ & $\begin{array}{l}\text { Creativity Research } \\
\text { Journal }\end{array}$ & Creativity tests \\
\hline $\begin{array}{l}\text { Irish National } \\
\text { Teachers' } \\
\text { Organization }\end{array}$ & 2009 & $\begin{array}{l}\text { "Creativity and the Arts in the } \\
\text { Primary School" }\end{array}$ & http://birbhum.nic.in & $\begin{array}{l}\text { Definition of } \\
\text { creativity }\end{array}$ \\
\hline Jolley, Richard & 2019 & $\begin{array}{l}\text { "The Importance of an Art } \\
\text { Education" }\end{array}$ & $\begin{array}{l}\text { https://cerp.aqa.org. } \\
\text { uk }\end{array}$ & $\begin{array}{l}\text { Art with } \\
\text { Creativity }\end{array}$ \\
\hline Kargi, Eda & 2018 & $\begin{array}{l}\text { "Reflections of Play and Toys on } \\
\text { Impressionist Painting Children } \\
\text { and Play as a Pictorial Expression" }\end{array}$ & $\begin{array}{l}\text { Creativity Research } \\
\text { Journal }\end{array}$ & $\begin{array}{l}\text { Art with } \\
\text { creativity }\end{array}$ \\
\hline
\end{tabular}


Continued Appendix

\begin{tabular}{|c|c|c|c|c|}
\hline First author & Year & Publication title & $\begin{array}{l}\text { Journal and book or } \\
\text { conference paper }\end{array}$ & $\begin{array}{l}\text { The reviewed } \\
\text { content under } \\
\text { the title of the } \\
\text { categories }\end{array}$ \\
\hline $\begin{array}{l}\text { Kaufman, } \\
\text { James C. }\end{array}$ & 2012 & $\begin{array}{l}\text { "Beyond New and Appropriate: } \\
\text { Who Decides What Is Creative?" }\end{array}$ & $\begin{array}{l}\text { Creativity Research } \\
\text { Journal }\end{array}$ & Creativity tests \\
\hline $\begin{array}{l}\text { Kaufmann, } \\
\text { Geir }\end{array}$ & 2003 & $\begin{array}{l}\text { "What to Measure? A New Look } \\
\text { at the Concept of Creativity" }\end{array}$ & $\begin{array}{l}\text { Scandinavian Journal } \\
\text { of Educational } \\
\text { Research } \\
\end{array}$ & $\begin{array}{l}\text { Definition of } \\
\text { creativity }\end{array}$ \\
\hline $\begin{array}{l}\text { Kim, Kyung } \\
\text { Hee }\end{array}$ & 2006 & $\begin{array}{l}\text { "Is Creativity Unidimensional } \\
\text { or Multidimensional? Analyses } \\
\text { of the Torrance Tests of Creative } \\
\text { Thinking" }\end{array}$ & $\begin{array}{l}\text { Creativity Research } \\
\text { Journal }\end{array}$ & Creativity tests \\
\hline $\begin{array}{l}\text { Kim, Kyung } \\
\text { Hee }\end{array}$ & 2011 & $\begin{array}{l}\text { "The APA } 2009 \text { Division } 10 \\
\text { Debate: Are the Torrance } \\
\text { Tests Still Relevant in the } 21 \text { st } \\
\text { Century?" }\end{array}$ & $\begin{array}{l}\text { Psychology of } \\
\text { Aesthetics, Creativity, } \\
\text { and the Arts }\end{array}$ & $\begin{array}{l}\text { Assessment of } \\
\text { creativity }\end{array}$ \\
\hline \begin{tabular}{|l|} 
Kingsborough \\
Community \\
College
\end{tabular} & 2001 & $\begin{array}{l}\text { "Guide for Analyzing Sculpture } \\
\text { and Painting" }\end{array}$ & $\begin{array}{l}\text { http://www.kbcc. } \\
\text { cuny.edu/ }\end{array}$ & $\begin{array}{l}\text { Art with } \\
\text { creativity }\end{array}$ \\
\hline $\begin{array}{l}\text { Kozbelt, } \\
\text { Aaron }\end{array}$ & 2006 & $\begin{array}{l}\text { "Dynamic Evaluation of Matisse’s } \\
1935 \text { Large Reclining Nude" }\end{array}$ & $\begin{array}{l}\text { Empirical Studies of } \\
\text { the Arts }\end{array}$ & $\begin{array}{l}\text { Criteria of } \\
\text { creativity } \\
\text { measurement }\end{array}$ \\
\hline Labno, Jeannie & 2008 & Renaissance & Metro Books & $\begin{array}{l}\text { Art with } \\
\text { creativity }\end{array}$ \\
\hline $\begin{array}{l}\text { Lebedeva, } \\
\text { Nadezhda }\end{array}$ & 2013 & $\begin{array}{l}\text { "Implicit Theories of } \\
\text { Innovativeness: Cross-Cultural } \\
\text { Analysis" }\end{array}$ & $\begin{array}{l}\text { WP5/10 Search } \\
\text { Working Paper }\end{array}$ & $\begin{array}{l}\text { Components of } \\
\text { creativity }\end{array}$ \\
\hline Lemons, Gay & 2011 & $\begin{array}{l}\text { "Diverse Perspectives of Creativity } \\
\text { Testing: Controversial Issues } \\
\text { when Used for Inclusion into } \\
\text { Gifted Programs" }\end{array}$ & $\begin{array}{l}\text { Journal for the } \\
\text { Education of the } \\
\text { Gifted }\end{array}$ & Creativity tests \\
\hline $\begin{array}{l}\text { Lindström, } \\
\text { Lars }\end{array}$ & 2006 & $\begin{array}{l}\text { "Creativity: What Is It? Can You } \\
\text { Assess It? Can It Be Taught?" }\end{array}$ & $\begin{array}{l}\text { The International } \\
\text { Journal of Art and } \\
\text { Design Education }\end{array}$ & $\begin{array}{l}\text { Scoring of } \\
\text { creativity } \\
\text { measurement }\end{array}$ \\
\hline Locher, Paul J. & 2010 & $\begin{array}{l}\text { "How Does a Visual Artist Create } \\
\text { an Artwork?" }\end{array}$ & $\begin{array}{l}\text { The Cambridge } \\
\text { Handbook of } \\
\text { Creativity }\end{array}$ & $\begin{array}{l}\text { Criteria of } \\
\text { creativity } \\
\text { measurement }\end{array}$ \\
\hline Meeker, Mary & 1978 & $\begin{array}{l}\text { "Measuring Creativity from the } \\
\text { Child's Point of View" }\end{array}$ & $\begin{array}{l}\text { Journal of Creative } \\
\text { Behavior }\end{array}$ & $\begin{array}{l}\text { Measurement of } \\
\text { creativity }\end{array}$ \\
\hline Mehta, Ravi & 2009 & $\begin{array}{l}\text { "Blue or Red? Exploring the } \\
\text { Effect of Color on Cognitive Task } \\
\text { Performances" }\end{array}$ & Science & $\begin{array}{l}\text { Criteria of } \\
\text { creativity } \\
\text { measurement }\end{array}$ \\
\hline $\begin{array}{l}\text { McKay, } \\
\text { Alexander S. }\end{array}$ & 2017 & $\begin{array}{l}\text { "Measuring the Muses: } \\
\text { Validating the Kaufman Domains } \\
\text { of Creativity Scale (K-DOCS)" }\end{array}$ & $\begin{array}{l}\text { Psychology of } \\
\text { Aesthetics, Creativity, } \\
\text { and the Arts } \\
\end{array}$ & Creativity tests \\
\hline $\begin{array}{l}\text { Okuda, Shawn } \\
\text { M. }\end{array}$ & 1991 & $\begin{array}{l}\text { "Creativity and the Finding and } \\
\text { Solving of Real-World Problems" }\end{array}$ & $\begin{array}{l}\text { Journal of } \\
\text { Psychoeducational } \\
\text { Assessment }\end{array}$ & $\begin{array}{l}\text { Components of } \\
\text { creativity }\end{array}$ \\
\hline
\end{tabular}


Continued Appendix

\begin{tabular}{|c|c|c|c|c|}
\hline First author & Year & Publication title & $\begin{array}{l}\text { Journal and book or } \\
\text { conference paper }\end{array}$ & $\begin{array}{l}\text { The reviewed } \\
\text { content under } \\
\text { the title of the } \\
\text { categories }\end{array}$ \\
\hline $\begin{array}{l}\text { Ormond, } \\
\text { Barbara }\end{array}$ & 2011 & $\begin{array}{l}\text { "Transformative Shifts in Art } \\
\text { History Teaching: The Impact of } \\
\text { Standards-Based Assessment" }\end{array}$ & $\begin{array}{l}\text { The Curriculum } \\
\text { Journal }\end{array}$ & $\begin{array}{l}\text { Scoring of } \\
\text { creativity } \\
\text { measurement } \\
\end{array}$ \\
\hline \begin{tabular}{|l|} 
Palmiero, \\
Massimiliano
\end{tabular} & 2016 & $\begin{array}{l}\text { "Editorial: Creativity and Mental } \\
\text { Imagery" }\end{array}$ & $\begin{array}{l}\text { Frontiers in } \\
\text { Psychology }\end{array}$ & $\begin{array}{l}\text { Components of } \\
\text { creativity }\end{array}$ \\
\hline $\begin{array}{l}\text { Perignat, } \\
\text { Elaine }\end{array}$ & 2018 & $\begin{array}{l}\text { "Book Review. From STEM to } \\
\text { STEAM: Using Brain-Compatible } \\
\text { Strategies to Integrate the Arts, by } \\
\text { David A. Sousa and Tom Pilecki } \\
\text { (2013). Thousand Oaks, CA: Sage" }\end{array}$ & $\begin{array}{l}\text { Arts Education Policy } \\
\text { Review }\end{array}$ & $\begin{array}{l}\text { Art with } \\
\text { creativity }\end{array}$ \\
\hline Piffer, Davide & 2012 & $\begin{array}{l}\text { "Can Creativity Be Measured? An } \\
\text { Attempt to Clarify the Notion of } \\
\text { Creativity and General Directions } \\
\text { for Future Research" }\end{array}$ & $\begin{array}{l}\text { Thinking Skills and } \\
\text { Creativity }\end{array}$ & $\begin{array}{l}\text { Measurement of } \\
\text { creativity }\end{array}$ \\
\hline $\begin{array}{l}\text { Plucker, } \\
\text { Jonathan A. }\end{array}$ & 2010 & "Assessment of Creativity" & $\begin{array}{l}\text { The Cambridge } \\
\text { Handbook of } \\
\text { Creativity }\end{array}$ & $\begin{array}{l}\text { Definition of } \\
\text { creativity }\end{array}$ \\
\hline $\begin{array}{l}\text { Rojas, } \\
\text { Joanne P. }\end{array}$ & 2018 & $\begin{array}{l}\text { "Measuring the Creative Process: } \\
\text { A Psychometric } \\
\text { Examination of Creative Ideation } \\
\text { and Grit" }\end{array}$ & $\begin{array}{l}\text { Creativity Research } \\
\text { Journal }\end{array}$ & Creativity tests \\
\hline $\begin{array}{l}\text { Roskos- } \\
\text { Ewoldsen, } \\
\text { Beverly }\end{array}$ & 2008 & $\begin{array}{l}\text { "Age-Related Changes in Creative } \\
\text { Thinking" }\end{array}$ & $\begin{array}{l}\text { Journal of Creative } \\
\text { Behavior }\end{array}$ & $\begin{array}{l}\text { Criteria of } \\
\text { creativity } \\
\text { measurement }\end{array}$ \\
\hline $\begin{array}{l}\text { Rostan, } \\
\text { Susan M. }\end{array}$ & 2002 & $\begin{array}{l}\text { "A Cross-Cultural Study of the } \\
\text { Development of Artistic Talent, } \\
\text { Creativity and Giftedness" }\end{array}$ & High Ability Studies & $\begin{array}{l}\text { Criteria of } \\
\text { creativity } \\
\text { measurement }\end{array}$ \\
\hline $\begin{array}{l}\text { Rostan, } \\
\text { Susan M. }\end{array}$ & 2005 & $\begin{array}{l}\text { "Educational Intervention and } \\
\text { the Development of Young Art } \\
\text { Students' Talent and Creativity" }\end{array}$ & $\begin{array}{l}\text { Journal of Creative } \\
\text { Behavior }\end{array}$ & $\begin{array}{l}\text { Scoring of } \\
\text { creativity } \\
\text { measurement }\end{array}$ \\
\hline $\begin{array}{l}\text { Runco, } \\
\text { Mark A. }\end{array}$ & 2011 & Encyclopedia of Creativity (Vol. 1) & Academic Press & Creativity tests \\
\hline $\begin{array}{l}\text { Runco, } \\
\text { Mark A. }\end{array}$ & 2012 & $\begin{array}{l}\text { "Divergent Thinking as an } \\
\text { Indicator of Creative Potential" }\end{array}$ & $\begin{array}{l}\text { Creativity Research } \\
\text { Journal }\end{array}$ & $\begin{array}{l}\text { Measurement of } \\
\text { creativity }\end{array}$ \\
\hline $\begin{array}{l}\text { Runco, } \\
\text { Mark A. }\end{array}$ & 2012 & $\begin{array}{l}\text { "The Standard Definition of } \\
\text { Creativity" }\end{array}$ & $\begin{array}{l}\text { Creativity Research } \\
\text { Journal }\end{array}$ & $\begin{array}{l}\text { Definition of } \\
\text { creativity }\end{array}$ \\
\hline $\begin{array}{l}\text { Runco, } \\
\text { Mark A. }\end{array}$ & 2014 & $\begin{array}{l}\text { "The Incremental Validity of a } \\
\text { Short Form of the Ideational } \\
\text { Behavior Scale and Usefulness of } \\
\text { Distractor, Contraindicative, and } \\
\text { Lie Scales" }\end{array}$ & $\begin{array}{l}\text { Journal of Creative } \\
\text { Behavior }\end{array}$ & Creativity tests \\
\hline $\begin{array}{l}\text { Runco, } \\
\text { Mark A. }\end{array}$ & 2016 & $\begin{array}{l}\text { "Which Test of Divergent } \\
\text { Thinking Is Best?" }\end{array}$ & $\begin{array}{l}\text { Creativity. } \\
\text { Theories - Research - } \\
\text { Applications }\end{array}$ & $\begin{array}{l}\text { Components of } \\
\text { creativity }\end{array}$ \\
\hline
\end{tabular}


End of Appendix

\begin{tabular}{|c|c|c|c|c|}
\hline First author & Year & Publication title & $\begin{array}{l}\text { Journal and book or } \\
\text { conference paper }\end{array}$ & $\begin{array}{l}\text { The reviewed } \\
\text { content under } \\
\text { the title of the } \\
\text { categories }\end{array}$ \\
\hline Scott, Sarah & 2006 & "Art and the Archaeologist" & World Archaeology & $\begin{array}{l}\text { Art with } \\
\text { creativity }\end{array}$ \\
\hline $\begin{array}{l}\text { Sternberg, } \\
\text { Robert J. }\end{array}$ & 2012 & $\begin{array}{l}\text { "The Assessment of Creativity: An } \\
\text { Investment-Based Approach" }\end{array}$ & $\begin{array}{l}\text { Creativity Research } \\
\text { Journal }\end{array}$ & $\begin{array}{l}\text { Criteria of } \\
\text { creativity } \\
\text { measurement }\end{array}$ \\
\hline $\begin{array}{l}\text { Tinio, Pablo } \\
\text { P. L. }\end{array}$ & 2013 & $\begin{array}{l}\text { "The Means to Art's End: Styles, } \\
\text { Creative Devices, and the } \\
\text { Challenge of Art" }\end{array}$ & $\begin{array}{l}\text { Neuroscience of } \\
\text { Creativity }\end{array}$ & $\begin{array}{l}\text { Criteria of } \\
\text { creativity } \\
\text { measurement }\end{array}$ \\
\hline $\begin{array}{l}\text { Torrance, } \\
\text { E. Paul }\end{array}$ & 2000 & $\begin{array}{l}\text { Research Review for the Torrance } \\
\text { Tests of Creative Thinking Figural } \\
\text { and Verbal Forms A and B }\end{array}$ & $\begin{array}{l}\text { Scholastic Testing } \\
\text { Service }\end{array}$ & $\begin{array}{l}\text { Assessment of } \\
\text { creativity }\end{array}$ \\
\hline $\begin{array}{l}\text { Urban, Klaus } \\
\text { K. }\end{array}$ & 2005 & $\begin{array}{l}\text { "Assessing Creativity: The Test } \\
\text { for Creative Thinking- Drawing } \\
\text { Production (TCT-DP): The } \\
\text { Concept, Application, Evaluation, } \\
\text { and International Studies" }\end{array}$ & $\begin{array}{l}\text { International } \\
\text { Education Journal }\end{array}$ & $\begin{array}{l}\text { Assessment of } \\
\text { creativity }\end{array}$ \\
\hline $\begin{array}{l}\text { United } \\
\text { Nations } \\
\text { Educational, } \\
\text { Scientific } \\
\text { and Cultural } \\
\text { Organization }\end{array}$ & 2006 & "Road Map for Arts Education" & $\begin{array}{l}\text { The World } \\
\text { Conference on Arts } \\
\text { Education: Building } \\
\text { Creative Capacities } \\
\text { for the 21st Century } \\
\text { (6-9 March, 2006. } \\
\text { Lisbon, Portugal) }\end{array}$ & $\begin{array}{l}\text { Components of } \\
\text { creativity }\end{array}$ \\
\hline $\begin{array}{l}\text { Vartanian, } \\
\text { Oshin }\end{array}$ & 2013 & $\begin{array}{l}\text { "Fostering Creativity: Insights } \\
\text { from Neuroscience" }\end{array}$ & $\begin{array}{l}\text { Neuroscience of } \\
\text { Creativity }\end{array}$ & $\begin{array}{l}\text { Components of } \\
\text { creativity }\end{array}$ \\
\hline $\begin{array}{l}\text { Vessey, } \\
\text { William B. }\end{array}$ & 2012 & $\begin{array}{l}\text { "Heuristics as a Basis for } \\
\text { Assessing Creative Potential: } \\
\text { Measures, Methods, and } \\
\text { Contingencies" }\end{array}$ & $\begin{array}{l}\text { Creativity Research } \\
\text { Journal }\end{array}$ & $\begin{array}{l}\text { Assessment of } \\
\text { creativity }\end{array}$ \\
\hline $\begin{array}{l}\text { Viskontas, } \\
\text { Indre V. }\end{array}$ & 2013 & $\begin{array}{l}\text { "Art and Dementia: How } \\
\text { Degeneration of Some Brain } \\
\text { Regions Can Lead to New } \\
\text { Creative Impulses" }\end{array}$ & $\begin{array}{l}\text { Neuroscience of } \\
\text { Creativity }\end{array}$ & $\begin{array}{l}\text { Measurement of } \\
\text { creativity }\end{array}$ \\
\hline $\begin{array}{l}\text { Wu, Ching- } \\
\text { Lin }\end{array}$ & 2017 & $\begin{array}{l}\text { "Enhancing the Measurement of } \\
\text { Remote Associative Ability: A } \\
\text { New Approach to Designing the } \\
\text { Chinese Remote Associates Test" }\end{array}$ & $\begin{array}{l}\text { Thinking Skills and } \\
\text { Creativity }\end{array}$ & Creativity tests \\
\hline $\begin{array}{l}\text { Yarbrough, } \\
\text { Nükhet D. }\end{array}$ & 2016 & $\begin{array}{l}\text { "Assessment of Creative Thinking } \\
\text { Across Cultures Using the } \\
\text { Torrance Tests of Creative } \\
\text { Thinking (TTCT): Translation } \\
\text { and Validity Issues" }\end{array}$ & $\begin{array}{l}\text { Creativity Research } \\
\text { Journal }\end{array}$ & $\begin{array}{l}\text { Assessment of } \\
\text { creativity }\end{array}$ \\
\hline $\begin{array}{l}\text { Zaidel, } \\
\text { Dahlia W. }\end{array}$ & 2013 & $\begin{array}{l}\text { "Biological and Neuronal } \\
\text { Underpinnings of Creativity in } \\
\text { the Arts" }\end{array}$ & $\begin{array}{l}\text { Neuroscience of } \\
\text { Creativity }\end{array}$ & $\begin{array}{l}\text { Definition of } \\
\text { creativity }\end{array}$ \\
\hline
\end{tabular}




\title{
STUDENTŲ VIZUALINIO MENINIO UGDYMO KŪRYBINIŲ GEBĖJIMŲ KRITERIJŲ APŽVALGA
}

\author{
Kani ULGER
}

\section{Santrauka}

Šiame tyrime siekiama numatyti vizualiųjų menų studijų studentų kūrybiškumą tapybos srityje. Šio tyrimo apžvalgos skelbiamos publikacijose. Šioje apžvalgoje hierarchiniu metodu išskiriamos tokios aštuonios kūrybiškumo kategorijos: apibrèžtis, komponentai, vertinimas, matavimas, kriterijai, testai, rezultatų sumavimas ir menas. Remiantis turinio analize, išskiriamos kategorijos - originalumas, sklandumas, lankstumas, ribų peržengimas neatsižvelgiant ị aplinkybes, netradiciškumas ir perspektyva; vertinant kūrybiškumą jos buvo apibrèžtos kaip universalūs bendrieji kriterijai. Vis dèlto estetiniai, techniniai igūdžiai, vaizduotė, tobulinimas, uždarumas ir idèjų kūrimas laikomi specifiniais kriterijais, matuojant tapybinị kūrybiškumą vizualinio meninio ugdymo srityje. Šis apžvalginis tyrimas atskleide, kad studentų vizualinio meninio ugdymo kūrybinius gebejimus galima numatyti remiantis abiejų - universalių ir specifinių - kriterijų deriniu.

Reikšminiai žodžiai: kūrybiškumas, kūrybiškumo matavimas, kūrybiškumo testai, kriterijai, vizualinis meninis ugdymas. 